OPEN ACCESS

Edited by:

Heather D. Bean,

Arizona State University, United States

Reviewed by:

Zehra Esra Ilhan,

INRAE Centre Jouy-en-Josas, France

Camila Marconi,

Federal University of Paraná, Brazil

*Correspondence:

Caroline M. Mitchell

Caroline.mitchell@mgh.harvard.edu

Specialty section:

This article was submitted to Microbiome in Health and Disease,

a section of the journal

Frontiers in Cellular and

Infection Microbiology

Received: 08 March 2021 Accepted: 28 June 2021

Published: 13 July 2021

Citation:

Vagios $S$ and Mitchell $C M$ (2021) Mutual Preservation:

A Review of Interactions

Between Cervicovaginal

Mucus and Microbiota.

Front. Cell. Infect. Microbiol. 11:676114.

do: 10.3389/fcimb.2021.676114

\section{Mutual Preservation: A Review of Interactions Between Cervicovaginal Mucus and Microbiota}

\author{
Stylianos Vagios and Caroline M. Mitchell ${ }^{*}$ \\ Department of Obstetrics \& Gynecology, Massachusetts General Hospital, Vincent Center for Reproductive Biology, \\ Massachusetts General Hospital Research Institute, Boston, MA, United States
}

At mucosal surfaces throughout the body mucus and mucins regulate interactions between epithelia and both commensal and pathogenic bacteria. Although the microbes in the female genital tract have been linked to multiple reproductive health outcomes, the role of cervicovaginal mucus in regulating genital tract microbes is largely unexplored. Mucus-microbe interactions could support the predominance of specific bacterial species and, conversely, commensal bacteria can influence mucus properties and its influence on reproductive health. Herein, we discuss the current evidence for both synergistic and antagonistic interactions between cervicovaginal mucus and the female genital tract microbiome, and how an improved understanding of these relationships could significantly improve women's health.

Keywords: cervicovaginal mucus, mucins, microbiome, female genital tract, reproductive health

\section{INTRODUCTION}

Mucus, a gel-like substance composed of mucins, glycans, proteins, cholesterol and water, coats the lumen of multiple organs and plays a key role in regulating interactions between microbiota and epithelial surfaces (Varki et al., 2015). In the lower female genital tract (FGT), endocervical mucus protects the mucosal surface and helps prevent infection through entrapment of pathogens. Mucus in the FGT is distinct from other sites in its cyclic variation with changes in reproductive hormones. There are clear links between properties of cervical mucus and reproductive health outcomes, however, our understanding of specific pathways by which mucus characteristics influence reproductive health remains limited (Curlin and Bursac, 2013; Nunn et al., 2015; Smith-Dupont et al., 2017; Fernandez-Hermida et al., 2018; Hoang et al., 2020; Lacroix et al., 2020; Najmabadi et al., 2021).

Mucus properties such as consistency and protein composition can affect the intestinal bacterial community. Gut microbiota use exposed mucin glycans as both sites of attachment and as sources of nutrition. Commensal bacteria can degrade mucus by the production of proteases and/or sialidases, can stimulate mucin secretion directly or through increased gene transcription mediated by Toll-like receptor family members and alter mucus properties through microbial-host interactions (Smirnova et al., 2003; Radtke et al., 2012; Johansson and Hansson, 2016). While interactions between gut bacteria and intestinal mucus have been well described, patterns in the FGT are less clear. 
Molecular classification of the microbiota has broadened our understanding of commensal bacteria in the FGT. In contrast to the gut, lower diversity of the microbial population in the vagina is associated with better reproductive health outcomes, such as lower incidence of bacterial vaginosis (BV), preterm birth and human immunodeficiency virus (HIV) acquisition (Gajer et al., 2012; DiGiulio et al., 2015; Gosmann et al., 2017). The vaginal microbiota is unique among body sites in that communities most associated with better clinical outcomes are low diversity, dominated by a single genus - Lactobacillus (Ravel et al., 2011; Anahtar et al., 2018). Sex hormones appear to have an important influence on composition of the vaginal microbiota (Johnson et al., 1985; Hillier and Lau, 1997; Eschenbach et al., 2000; Farage and Maibach, 2006; Bezirtzoglou et al., 2008), and also regulate qualities of cervicovaginal mucus (Table 1) (Chappell et al., 2014). The vaginal microbial community changes with hormonal transitions such as menarche, menses, pregnancy, and menopause (Zhou et al., 2007; Gajer et al., 2012; Hickey et al., 2015; Gliniewicz et al., 2019).

The contribution of cervicovaginal mucus to the composition of the FGT microbiome is unknown. Here we review what is known of the impact of cervicovaginal mucus on vaginal microbiota and vice versa. We discuss FGT mucus structure, how mucin properties regulate microbiota and how "optimal" and "non-optimal" bacterial populations modulate CVM. The purpose of this review is to provide an updated overview of the current knowledge, identify gaps, and suggest future directions for research.

\section{CERVICOVAGINAL MUCUS COMPOSITION}

Cervical mucus is produced by epithelial cells within cervical crypts and is composed mainly of water, and a complex mixture of proteins, lipids, cholesterol, and inorganic ions. Mucins are glycoproteins that serve as a major structural component of mucus and are responsible for its viscous properties. Two types of mucins can be found in cervical mucus: secreted or gelforming (MUC2, MUC5AC, MUC5B, and MUC6) and membrane-spanning (MUC1, MUC4, and MUC16) (Gipson et al., 1997; Gipson, 2001). The dominant gel-forming mucus is MUC5B and the major membrane-spanning mucus is MUC4

TABLE 1 | Changes in cervicovaginal mucus properties and microbiome across menstrual phases and significant hormonal changes with menopause or pregnancy.

\begin{tabular}{|c|c|c|c|c|c|c|}
\hline & \multicolumn{4}{|c|}{ Not Pregnant } & \multirow[t]{2}{*}{ Pregnant } & \multirow[t]{2}{*}{ References } \\
\hline & $\begin{array}{l}\text { Follicular } \\
\text { phase }\end{array}$ & $\begin{array}{l}\text { Ovulatory } \\
\text { phase }\end{array}$ & $\begin{array}{l}\text { Luteal } \\
\text { phase }\end{array}$ & Menopause & & \\
\hline Mucus Type & G- & $S, L$ & $\mathrm{G}+$ & $\mathrm{n} / \mathrm{a}$ & $\mathrm{G}^{* *}(\mathrm{Gp})$ & (Odeblad, 1983; Odeblad, 1997) \\
\hline Amount & $\downarrow$ & $\uparrow$ & $\downarrow$ & $\downarrow$ & $\uparrow$ & (Reynoso-Prieto et al., 2019) \\
\hline Viscosity & + & - & ++ & + & ++ & (Odeblad, 1983; Odeblad, 1997) \\
\hline Water content & Low & High & Low & Low & Low & $\begin{array}{l}\text { (Curlin and Bursac, 2013; } \\
\text { Reynoso-Prieto et al., 2019) }\end{array}$ \\
\hline \multicolumn{7}{|l|}{ Mucin concentration } \\
\hline MUC1 & High & High & Low & Low & $\mathrm{n} / \mathrm{a}$ & $\begin{array}{l}\text { (Huggins and Preti, 1981; Moncla } \\
\text { et al., 2016) }\end{array}$ \\
\hline MUC4 & Low & High & Low & Low & & \\
\hline MUC5B & Low & High & Low & Low & & \\
\hline MUC5AC & No dif. & No dif. & No dif. & No dif. & & \\
\hline MUC7 & No dif. & No dif. & No dif. & & & \\
\hline Glycan concentration & + & ++ & - & $\mathrm{n} / \mathrm{a}$ & $\mathrm{n} / \mathrm{a}$ & (Andersch-Bjorkman et al., 2007) \\
\hline $\begin{array}{l}\text { Oligosaccharides } \\
\text { acidic profile }\end{array}$ & $\begin{array}{l}\text { More } \\
\text { acidic }\end{array}$ & $\begin{array}{c}\text { More } \\
\text { neutral }\end{array}$ & $\begin{array}{l}\text { More } \\
\text { acidic }\end{array}$ & $\mathrm{n} / \mathrm{a}$ & $\mathrm{n} / \mathrm{a}$ & $\begin{array}{l}\text { (Argueso et al., 2002; } \\
\text { Andersch-Bjorkman et al., 2007) }\end{array}$ \\
\hline Total protein & + & - & + & $\mathrm{n} / \mathrm{a}$ & $\mathrm{n} / \mathrm{a}$ & (Reynoso-Prieto et al., 2019) \\
\hline Lactoferrin & +++ & + & ++ & - & - & $\begin{array}{l}\text { (Mitsukawa et al., 2006; Keller et al., } \\
\text { 2007; Becher et al., 2009; Wira et al., } \\
\text { 2011) }\end{array}$ \\
\hline Immunoglobulins & + & - & + & $\mathrm{n} / \mathrm{a}$ & ++ & (Schumacher et al., 1977) \\
\hline Lysozyme & + & - & + & - & - & (Schumacher et al., 1977) \\
\hline Defensins & +++ & + & ++ & - & + & $\begin{array}{l}\text { (Keller et al., 2007; Xu et al., 2008; } \\
\text { Wira et al., 2011) }\end{array}$ \\
\hline $\begin{array}{l}\text { Secretory leukocyte } \\
\text { protease inhibitor } \\
\text { (SLPI) }\end{array}$ & +++ & + & ++ & + & ++ & $\begin{array}{l}\text { (Shimoya et al., 2006; Keller et al., } \\
\text { 2007; Wira et al., 2011) }\end{array}$ \\
\hline Microbiome & \multicolumn{3}{|c|}{$\begin{array}{l}\text { Progressive increase in } \\
\text { Lactobacillus spp. concentration } \\
\text { Progressive decrease in non- } \\
\text { Lactobacillus spp. concentration }\end{array}$} & $\begin{array}{l}\text { Decreased concentration of } \\
\text { Lactobacillus and BV-associated } \\
\text { bacteria }\end{array}$ & $\begin{array}{l}\text { Less rich, less diverse, } \\
\text { increase in Lactobacillus } \\
\text { concentration }\end{array}$ & $\begin{array}{l}\text { (Hillier and Lau, 1997; Eschenbach } \\
\text { et al., 2000; Gupta et al., 2020) }\end{array}$ \\
\hline
\end{tabular}

$\uparrow=$ increased; $\downarrow=$ decreased; - = no change; number of + indicates relative concentration in vaginal fluid; n/a = no data available. 
(Gipson et al., 1999; Gipson, 2001). The combination of cervical mucus secreted from the os and vaginal fluid (i.e. secretions from the Bartholin's and Skene's glands, plasma transudate, exfoliated cells, bacterial byproducts, bacteria and local immune cell secretions) is termed cervicovaginal mucus (CVM) (Huggins and Preti, 1981; Henderson et al., 2007; Srinivasan and Fredricks, 2008; Zegels et al., 2010). Vaginal epithelial cell MUC gene expression is lower than endocervical cells, suggesting that most mucins come from the cervix (Gipson et al., 1997).

Historically, gynecologists described four main types of cervical mucus (G-, G+, L, and S), all defined by the impact on fertility (Table 1) (Odeblad, 1983). At the beginning of luteal phase, viscous G- mucous has a substantial amount of white blood cells and acts as a barrier to semen ascension to the uterus. Increasing progesterone through the luteal phase supports a more viscous mucous type $\mathrm{G}+$, containing more white blood cells, increasing the barrier to ascent of sperm. With rising estrogen in the follicular phase, type L contains fewer white blood cells, has medium viscosity, and allows more sperm motility. At peak estrogen around ovulation, type $S$ has minimal viscosity and no white blood cells, allowing sperm to reach the uterus (Odeblad, 1983; Odeblad, 1997; Menarguez et al., 2003).

These historical descriptions primarily capture biologic variation in the consistency and amount of CVM. Biochemically, mucin secretion also varies within the menstrual cycle. An inverse correlation exists between serum progesterone levels and MUC5B mRNA expression (Gipson et al., 1999) while total cervical mucus and MUC5B secretion correlate positively with estrogen levels. Therefore, MUC5B is at its highest levels midcycle, and drops significantly in the luteal phase (Gipson et al., 2001). Expression of the transmembrane mucin MUC4 follows a similar pattern with a peak at midcycle and drop in the luteal phase (Gipson et al., 1999). The high midcycle water content of hydrophilic MUC5B may create a more patent endocervical canal, facilitating sperm motility and penetrance (Gipson et al., 2001). The glycosylation status of mucins also varies with the menstrual cycle, demonstrating increased carbohydrate concentration in secreted mucins and more neutral ( $v s$. acidic) oligosaccharides at midcycle (Argueso et al., 2002; Andersch-Bjorkman et al., 2007).

\section{IMPACT OF CERVICOVAGINAL MUCUS ON GENITAL MICROBIOTA}

Mucus in the FGT serves both as physical and biochemical barrier against infectious pathogens. CVM contains immunoglobulins, antibacterial enzymes and antibacterial peptides, such as lysozyme, lactoferrin and defensins (Mitchell et al., 2015; Adnane et al., 2018; Elovitz et al., 2019). In mice, colonic epithelia mucus layers densely populated with MUC2 create a physical barrier that blocks bacteria-epithelium interaction (Johansson et al., 2008). Proteolytic cleavage of MUC2 loosens the structure of the outer intestinal mucus layer, allowing bacteria to colonize (Johansson et al., 2008).
Moreover, mucus serves as a physical trap for particles (Bakshani et al., 2018). Cell-surface mucins can act as ligands for mucosal pathogens; the cell subsequently discards the extracellular mucus component to which pathogens are attached (Dhar and McAuley, 2019). In the FGT, CVM can trap organisms as small as herpes simplex virus (Schroeder et al., 2018). In vitro, mucins trap human immunodeficiency virus-1 (HIV-1) to a greater degree than similarly sized particles, suggesting charge-based or pathogen-specific effects beyond physical trapping (Mall et al., 2017).

Mucus may also drive the composition of the commensal vaginal microbial community (Figure 1A). Bacterial adhesion to mucins and glycans is proposed as a means of host positive selection of beneficial microbes (McLoughlin et al., 2016). The intestinal mucus layer serves as a natural habitat for "mucusassociated microorganisms" by serving as an attachment site (Paone and Cani, 2020). In the gastrointestinal tract, commensal lactobacilli have genes encoding mucin binding protein or other binding factors allowing adhesion to mucins. Similar genomic features are noted in L. crispatus and L. gasseri, two of the most common bacteria of the vaginal microbiota (Boekhorst et al., 2006; Velez et al., 2007; Van Tassell and Miller, 2011; Dudik et al., 2020). The ability to use CVM may facilitate Lactobacillus dominance of the vaginal microbiome.

Differences in glycosylation profile add additional intraindividual variability, and may be linked to traits such as blood type or secretor status (Thomsson et al., 2005). In the gut, secretor status and/or blood type is associated with differences in microbial colonization (Rausch et al., 2011; Davenport et al., 2016; Gampa et al., 2017; Kolde et al., 2018). Few studies examine the role of mucins in driving FGT microbial communities. Changes in mucin composition due to hormones, or disruption of CVM by pathogen mucinase activity could limit Lactobacillus binding, and "non-optimal" microbial populations could prevail (Dudik et al., 2020). In the gut, different mucin glycosylation patterns are instrumental to microbial tropism (Tailford et al., 2015). In vitro experiments demonstrate that $H$. pylori rarely grows in a mucin environment rich in a 1,4-GlcNAc-capped O-glycans (Kobayashi et al., 2009) and that transaldolase is an important factor promoting Bifidobacterium bifidum colonization (Gonzalez-Rodriguez et al., 2012).

Nutrient availability in cervicovaginal mucus could also drive shifts in community. Carbon sources such as glycogen are associated with Lactobacillus-dominant microbial populations (Mirmonsef et al., 2014). However, most lactobacilli present in the lower FGT do not directly metabolize glycogen, rather relying on glycogen degradation by host $\alpha$-amylase (Spear et al., 2014; Nasioudis et al., 2015). There are some amylase-producing species of lactobacilli (e.g. L. fermentum) (Padmavathi et al., 2018). L. crispatus strains with a putative pullalanase type I gene can grow with glycogen as a carbon source, suggesting some strains may be able to directly utilize this sugar (van Der Veer et al., 2019). There is significant intraindividual variability in FGT glycogen concentrations and prolonged low glycogen states such as those seen in postmenopausal women favor microbial 


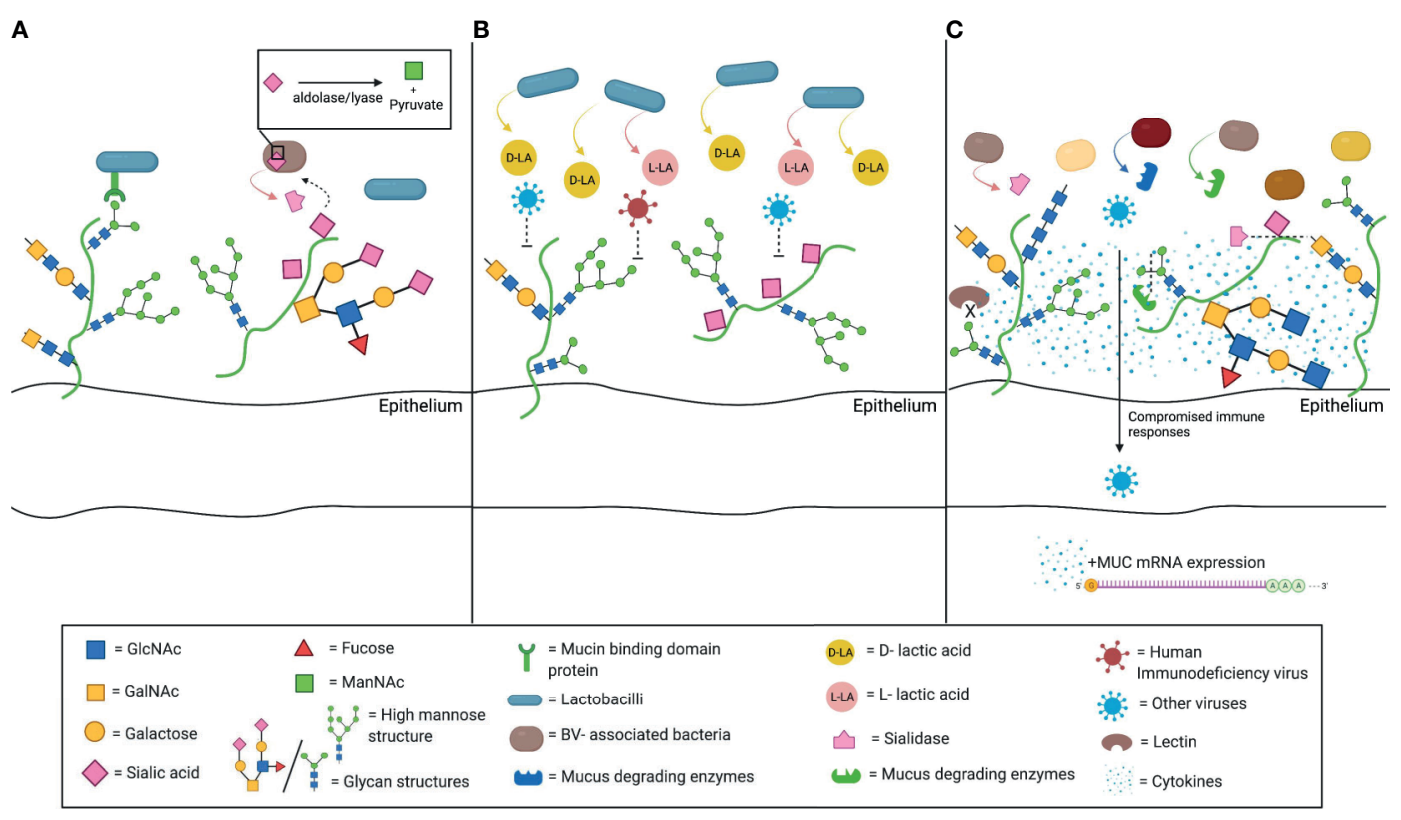

FIGURE 1 | Schematic depiction of interactions between cervicovaginal mucus (CVM) and microbiota. (A) CVM may drive the composition of the commensal vaginal microbial community. Mucin binding protein (MucBP) domains and other binding factors allowing adhesion to mucins have been found on several lactobacilli, including the common vaginal species $L$. crispatus and $L$. gasseri. In addition, mucus constituents can be used as nutrient sources by commensal bacteria. Sialidase producing bacteria are able to catabolize the sialic acid present on mucins through an internal aldolase/lyase reaction. (B) Beneficial microbes, such as $L$. crispatus, also drive functional changes in the CVM. L. crispatus produces both D-lactic acid (D-LA) and L-LA, and CVM from women with L. crispatus-dominance has been associated with increased entrapment of viruses, including human immunodeficiency virus (HIV). (C) Bacterial vaginosis (BV)- associated bacteria can alter CVM properties. They may express sialidase and other mucus degrading enzymes, such as mucinases or other galactosidases. Sialidase production is associated with many of the adverse health outcomes related with BV, such as preterm birth, intrauterine infection during pregnancy, or invading infection. The lower sialic acid and the high mannose abundance, that have been correlated with BV-associated bacteria populations, along with the associated impaired lectin binding further compromise that innate immune responses in the lower genital tract. The resulting inflammatory environment has been shown to increased mucin mRNA expression and abundance (Figure created with BioRender.com).

populations not dominated by lactobacilli (Mirmonsef et al., 2014; Mirmonsef et al., 2015). Similarly, mucins could also serve as a nutrient source for a number of bacteria. Human-derived mucins from different intestinal sites revealed over one hundred different oligosaccharides, which intestinal microbiota use as an energy source. The variety of carbon sources in mucins could contribute to different patterns of bacterial colonization along the gastrointestinal tract (Robbe et al., 2004). Several microorganisms found commensally in the vagina produce enzymes like glycosidases and proteinases, allowing them to degrade mucins and consume their glycans (Lewis et al., 2013; Werlang et al., 2019). Sialidase positive bacteria, such as Gardnerella vaginalis or Prevotella bivia, are able to catabolize sialic acid in the cervicovaginal mucins, releasing Neu5Ac (Smayevsky et al., 2001; Santiago et al., 2012; Lewis et al., 2013; Gilbert et al., 2019; Agarwal et al., 2020). They transport Neu5Ac intracellularly and catabolize it by an aldolase/lyase reaction (Lewis et al., 2013) which may confer a survival benefit in some nutrient deprived situations (Olmsted et al., 2003). Synergy between pathogenic species is also demonstrated by glycan cross-feeding supporting the concurrent growth of BVassociated species G. vaginalis and Fusobacterium nucleatum, a pathogen linked to intrauterine infection (Agarwal et al., 2020).
Mucins can regulate microbial gene expression, which may influence microbial colonization and function. MUC5AC, MUC2 and MUC5B exhibit potent inhibition of Candida albicans, a common pathogen of the FGT, downregulating virulence genes and inhibiting formation of hyphae (Kavanaugh et al., 2014). These same mucins downregulate virulence genes in the respiratory pathogen $P$. aeruginosa and decrease biofilm formation (Wheeler et al., 2019). Pre-incubation of $L$. reuteri (a common gut species) with gastric mucin led to greater adherence to HT-29 colon epithelial cells, and upregulation of bacterial surface adhesion proteins (Dudik et al., 2020). Apart from C. albicans, few genital tract microbes have been evaluated in these types of experiments.

Commensal bacteria co-exist in a fine balance with host innate immune responses. In addition to physical and nutrient properties, antimicrobial factors found in mucus may play a role in ensuring peaceful equilibrium. In the gut, regenerating family member 3 (REG3) protein (an antibacterial lectin) creates a zone of limited contact between the microbiota and the epithelium, ensuring immune quiescence. Commensal bacteria induce greater immune responses in REG3-gamma deficient mice (Vaishnava et al., 2011). In the respiratory tract, MUC1 can act as a negative regulator of inflammation induced through toll-like receptor 
(TLR) pathways (Dhar and McAuley, 2019). In the cervix, several antimicrobial peptides are found in mucus (e.g. secretory leukocyte protease inhibitor -SLPI-, lactoferrin, cathelicidin, defensins). SLPI, a potent inhibitor of leukocyte elastase, cathepsin G, and trypsin, is produced at the endocervical epithelium and is present in the cervical tissue and mucus (Moriyama et al., 1999). Epithelial and immune cells contribute to the production of other antimicrobial peptides found in the CVM such as $\beta$-defensins, elafin, calprotectin, cathelicidin, lactoferrin, $\alpha$-defensins and lysozyme (Hein et al., 2002; Valore et al., 2002; Klotman and Chang, 2006; Keller et al., 2007; Levinson et al., 2009; Ghosh et al., 2010; Shust et al., 2010; Wira et al., 2011; Yarbrough et al., 2015). Regulation of these peptides in the FGT with hormonal cycles has been described (Table 1), but their integration with mucins, geographic orientation in the mucus layer and interaction with microbes at the mucosal surface have not been evaluated.

Focused research on whether and how CVM mucins and glycans influence vaginal colonization by particular microbiota, and how they modulate host-microbe interactions will likely offer new perspectives on how to promote optimal vaginal health.

\section{INFLUENCE OF "OPTIMAL" AND "NON-OPTIMAL" MICROBIOTA ON CERVICOVAGINAL MUCUS}

In the gut, the commensal bacteria composition induces changes in intestinal mucus (Schroeder, 2019). In mice, gut microbiota promote production of proper mucus by affecting goblet cell numbers (Schroeder, 2019). In addition, the microbiota activate an enzyme, meprin $\beta$ protease, necessary for the release of mucous from goblet cells (Johansson et al., 2015). The gut microbiota also influence mucin glycosylation profiles and local mucus thickness (Li et al., 2015; Corfield, 2018; Paone and Cani, 2020). In the FGT, sex hormone levels clearly impact mucus properties, and have been associated with changes in microbiota (Table 1). However, the impact of the local microbial community on CVM is incompletely described (Nunn et al., 2015).

\section{Interaction of "Non-Optimal" Cervicovaginal Microbiota With Mucins}

Several bacteria associated with BV have the ability to degrade mucus (Briselden et al., 1992; Howe et al., 1999; Ravel et al., 2011). BV, a common cause of vaginal discharge, is characterized by a polymicrobial imbalance in favor of anaerobic bacteria, and is associated with increased rates of sexually transmitted infections (STIs), pelvic inflammatory disease (PID), and unfavorable obstetric outcomes (Hillier et al., 1988; Hillier et al., 1995; Svare et al., 2006; Brotman et al., 2010; Cohen et al., 2012). Sialic acid (SA) is a significant mucin glycan; the specific SA residue and attached sugars are crucial determinants of its function (Schauer, 2009). Production of the SA-degrading enzyme, sialidase, has been detected in a number of strains of Gardnerella, Prevotella, Bacteroides, and other BV-associated bacterial species (Figure 1A) (Briselden et al., 1992; Smayevsky et al., 2001; Santiago et al., 2011; Lewis et al., 2013). Lower SA concentrations are detected in women with BV (Smayevsky et al., 2001). Degradation of mucus by sialidase may contribute the watery discharge seen in BV, while elimination of the cervical mucus barrier may facilitate upper genital tract infection (Santiago et al., 2011).

The removal of SA residues renders mucins vulnerable to further degradation by proteases secreted by BV-associated bacteria and other pathogens such as Trichomonas vaginalis (Lehker and Sweeney, 1999; Kairys and Garg, 2020). BVassociated bacterial species secrete a variety of other mucus degrading enzymes, such as mucinases, sulfatases, galactosidases, and prolidases. These likely also impact the mucus barrier, though are less thoroughly studied (Howe et al., 1999; Cauci et al., 2005; Pleckaityte et al., 2012; Moncla et al., 2016). Alterations in physical and biochemical properties of mucus have been linked to preterm birth and intrauterine infection (Critchfield et al., 2013; Smith-Dupont et al., 2017), as have alterations in microbiota (DiGiulio et al., 2015). Sialidase levels, likely driven by BV-associated microbes, independently correlate with these obstetric complications (McGregor et al., 1994; Cauci and Culhane, 2011). Additional mucus alterations seen in women with BV, such as lower high mannose glycans, suggest other pathways through which bacterial communities may increase susceptibility to infections (Moncla et al., 2016).

Furthermore, the bacterial community in the FGT can induce production of mucus and mucins (Figure 1C). Women with BV have higher levels of MUC1, MUC4, MUC5AC, MUC5B and MUC7 than women without BV (Borgdorff et al., 2016; Moncla et al., 2016). This may be due to direct stimulation by BVassociated organisms and their byproducts, (Dohrman et al., 1998; Radtke et al., 2012) or BV-associated inflammation triggering mRNA upregulation (Li et al., 2003; Smirnova et al., 2003). Alternatively, increased mucin production may be a reaction to degradation by enzymes secreted by $\mathrm{BV}$ associated microbes.

\section{Effect of "Optimal" Cervicovaginal Microbiota on Cervicovaginal Mucus Function}

Beneficial microbes drive functional changes in mucus. CVM from women with $L$. crispatus-dominated vaginal microbiota prevents in vitro HIV infection better than CVM from women with diverse microbial communities (Figure 1B) (Lai et al., 2009). This enhanced protection appears to be due in part to the presence of metabolites from the lactobacilli, specifically Dlactic acid (D-LA), produced by L. crispatus but not L. iners (Boskey et al., 2001; Witkin et al., 2013; Nunn et al., 2015). The acidity supports hydrogen bonding between the viral surface and mucin carboxyl groups, though the reason for the difference in efficacy between the D- and L- isomers is not clear. 


\section{FUTURE RESEARCH DIRECTIONS}

In contrast to the gastrointestinal tract (Etienne-Mesmin et al., 2019), the FGT has limited experimental models in which to study mucin - microbiota interactions (Herbst-Kralovetz et al., 2016). One commonly used immortalized endocervical epithelial cell line is generally considered not to produce mucus (End1) while another does (A2EN) (Radtke et al., 2012). Collection of cervical mucus and assessment of physical and biochemical properties in vitro, or co-culture of microbes and mucus or mucins have provided additional insight (Muscariello et al., 2020). The source and processing of mucins for use in these experiments is important to retain their in vivo biologic activity (Kavanaugh et al., 2014; Wheeler et al., 2019). It is hoped that novel "organ-on-a-chip" technology can develop more comprehensive and high-fidelity models for study of mucinmicrobe interactions in a more holistic manner (Ingber, 2021).

\section{CONCLUSION}

Mucus in the FGT has a clear association with vaginal microbiota, reproductive health outcomes and mucosal immune responses but is the least well understood part of that triumvirate. Cervicovaginal mucus is easily accessible, but model systems to facilitate research in this field are not widely available. In the gastrointestinal tract animal models have contributed

\section{REFERENCES}

Adnane, M., Meade, K. G., and O'farrelly, C. (2018). Cervico-Vaginal Mucus (CVM) - an Accessible Source of Immunologically Informative Biomolecules. Vet. Res. Commun. 42, 255-263. doi: 10.1007/s11259-018-9734-0

Agarwal, K., Robinson, L. S., Aggarwal, S., Foster, L. R., Hernandez-Leyva, A., Lin, H., et al. (2020). Glycan Cross-Feeding Supports Mutualism Between Fusobacterium and the Vaginal Microbiota. PloS Biol. 18, e3000788. doi: 10.1371/journal.pbio.3000788

Anahtar, M. N., Gootenberg, D. B., Mitchell, C. M., and Kwon, D. S. (2018). Cervicovaginal Microbiota and Reproductive Health: The Virtue of Simplicity. Cell Host Microbe 23, 159-168. doi: 10.1016/j.chom.2018.01.013

Andersch-Bjorkman, Y., Thomsson, K. A., Holmen Larsson, J. M., Ekerhovd, E., and Hansson, G. C. (2007). Large Scale Identification of Proteins, Mucins, and Their O-Glycosylation in the Endocervical Mucus During the Menstrual Cycle. Mol. Cell Proteomics 6, 708-716. doi: 10.1074/mcp.M600439-MCP200

Argueso, P., Spurr-Michaud, S., Tisdale, A., and Gipson, I. K. (2002). Variation in the Amount of $\mathrm{T}$ Antigen and $\mathrm{N}$-Acetyllactosamine Oligosaccharides in Human Cervical Mucus Secretions With the Menstrual Cycle. J. Clin. Endocrinol. Metab. 87, 5641-5648. doi: 10.1210/jc.2002-020766

Bakshani, C. R., Morales-Garcia, A. L., Althaus, M., Wilcox, M. D., Pearson, J. P., Bythell, J. C., et al. (2018). Evolutionary Conservation of the Antimicrobial Function of Mucus: A First Defence Against Infection. NPJ Biofilms Microbiomes 4, 14. doi: 10.1038/s41522-018-0057-2

Becher, N., Adams Waldorf, K., Hein, M., and Uldbjerg, N. (2009). The Cervical Mucus Plug: Structured Review of the Literature. Acta Obstet. Gynecol. Scand. 88, 502-513. doi: 10.1080/00016340902852898

Bezirtzoglou, E., Voidarou, C., Papadaki, A., Tsiotsias, A., Kotsovolou, O., and Konstandi, M. (2008). Hormone Therapy Alters the Composition of the Vaginal Microflora in Ovariectomized Rats. Microb. Ecol. 55, 751-759. doi: 10.1007/s00248-007-9317-z

Boekhorst, J., Helmer, Q., Kleerebezem, M., and Siezen, R. J. (2006). Comparative Analysis of Proteins With a Mucus-Binding Domain Found Exclusively in significantly to our appreciation of interactions between mucus, commensal bacteria, and host immune responses. It seems likely that mucus and mucins play a similar role in the FGT: regulating and modulating interactions between host and microbiota through availability of binding sites or nutrients and modulating physical host-microbe interactions. Conversely, pathogenic bacteria may change FGT mucus properties, undermining its role in preventing infection or inflammation, leading to adverse gynecologic and obstetric outcomes. A better understanding of interactions between CVM and cervicovaginal microbiota could help explain the pathophysiology behind numerous gynecologic and obstetric outcomes, and significantly improve women's health.

\section{AUTHOR CONTRIBUTIONS}

SV and CM drafted and revised the manuscript. All authors contributed to the article and approved the submitted version.

\section{FUNDING}

This work was supported in part by a Harvard Catalyst Microbiome Pilot award and the Vincent Memorial Research Funds. Neither funder participated in design or execution of the work.

Lactic Acid Bacteria. Microbiology (Reading) 152, 273-280. doi: 10.1099/ mic. $0.28415-0$

Borgdorff, H., Gautam, R., Armstrong, S. D., Xia, D., Ndayisaba, G. F., Van Teijlingen, N. H., et al. (2016). Cervicovaginal Microbiome Dysbiosis Is Associated With Proteome Changes Related to Alterations of the Cervicovaginal Mucosal Barrier. Mucosal Immunol. 9, 621-633. doi: 10.1038/ mi.2015.86

Boskey, E. R., Cone, R. A., Whaley, K. J., and Moench, T. R. (2001). Origins of Vaginal Acidity: High D/L Lactate Ratio Is Consistent With Bacteria Being the Primary Source. Hum. Reprod. 16, 1809-1813. doi: 10.1093/humrep/16.9.1809

Briselden, A. M., Moncla, B. J., Stevens, C. E., and Hillier, S. L. (1992). Sialidases (Neuraminidases) in Bacterial Vaginosis and Bacterial Vaginosis-Associated Microflora. J. Clin. Microbiol. 30, 663-666. doi: 10.1128/jcm.30.3.663-666.1992 Brotman, R. M., Klebanoff, M. A., Nansel, T. R., Yu, K. F., Andrews, W. W., Zhang, J., et al. (2010). Bacterial Vaginosis Assessed by Gram Stain and Diminished Colonization Resistance to Incident Gonococcal, Chlamydial, and Trichomonal Genital Infection. J. Infect. Dis. 202, 1907-1915. doi: 10.1086/ 657320

Cauci, S., and Culhane, J. F. (2011). High Sialidase Levels Increase Preterm Birth Risk Among Women Who are Bacterial Vaginosis-Positive in Early Gestation. Am. J. Obstet. Gynecol. 204, 142.e141-149. doi: 10.1016/j.ajog.2010.08.061

Cauci, S., McGregor, J., Thorsen, P., Grove, J., and Guaschino, S. (2005). Combination of Vaginal $\mathrm{pH}$ With Vaginal Sialidase and Prolidase Activities for Prediction of Low Birth Weight and Preterm Birth. Am. J. Obstet. Gynecol. 192, 489-496. doi: 10.1016/j.ajog.2004.07.023

Chappell, C. A., Rohan, L. C., Moncla, B. J., Wang, L., Meyn, L. A., Bunge, K., et al. (2014). The Effects of Reproductive Hormones on the Physical Properties of Cervicovaginal Fluid. Am. J. Obstet. Gynecol. 211, 226.e221-227. doi: 10.1016/ j.ajog.2014.03.041

Cohen, C. R., Lingappa, J. R., Baeten, J. M., Ngayo, M. O., Spiegel, C. A., Hong, T., et al. (2012). Bacterial Vaginosis Associated With Increased Risk of Female-toMale HIV-1 Transmission: A Prospective Cohort Analysis Among African Couples. PloS Med. 9, e1001251. doi: 10.1371/journal.pmed.1001251 
Corfield, A. P. (2018). The Interaction of the Gut Microbiota With the Mucus Barrier in Health and Disease in Human. Microorganisms 6 (3), 78. doi: 10.3390/microorganisms6030078

Critchfield, A. S., Yao, G., Jaishankar, A., Friedlander, R. S., Lieleg, O., Doyle, P. S., et al. (2013). Cervical Mucus Properties Stratify Risk for Preterm Birth. PloS One 8, e69528. doi: 10.1371/journal.pone.0069528

Curlin, M., and Bursac, D. (2013). Cervical Mucus: From Biochemical Structure to Clinical Implications. Front. Biosci. (Schol. Ed.) 5, 507-515. doi: 10.2741/S386

Davenport, E. R., Goodrich, J. K., Bell, J. T., Spector, T. D., Ley, R. E., and Clark, A. G. (2016). ABO Antigen and Secretor Statuses are Not Associated With Gut Microbiota Composition in 1,500 Twins. BMC Genomics 17, 941. doi: 10.1186/ s12864-016-3290-1

Dhar, P., and McAuley, J. (2019). The Role of the Cell Surface Mucin MUC1 as a Barrier to Infection and Regulator of Inflammation. Front. Cell. Infect. Microbiol. 9, 117. doi: 10.3389/fcimb.2019.00117

DiGiulio, D. B., Callahan, B. J., Mcmurdie, P. J., Costello, E. K., Lyell, D. J., Robaczewska, A., et al. (2015). Temporal and Spatial Variation of the Human Microbiota During Pregnancy. Proc. Natl. Acad. Sci. U.S.A. 112, 11060-11065. doi: $10.1073 /$ pnas.1502875112

Dohrman, A., Miyata, S., Gallup, M., Li, J. D., Chapelin, C., Coste, A., et al. (1998). Mucin Gene (MUC 2 and MUC 5AC) Upregulation by Gram-Positive and Gram-Negative Bacteria. Biochim. Biophys. Acta 1406, 251-259. doi: 10.1016/ S0925-4439(98)00010-6

Dudik, B., Kinova Sepova, H., Bilka, F., Paskova, L., and Bilkova, A. (2020). Mucin Pre-Cultivated Lactobacillus Reuteri E Shows Enhanced Adhesion and Increases Mucin Expression in HT-29 Cells. Antonie Van Leeuwenhoek 113, 1191-1200. doi: 10.1007/s10482-020-01426-1

Elovitz, M. A., Gajer, P., Riis, V., Brown, A. G., Humphrys, M. S., Holm, J. B., et al. (2019). Cervicovaginal Microbiota and Local Immune Response Modulate the Risk of Spontaneous Preterm Delivery. Nat. Commun. 10, 1305. doi: 10.1038/ s41467-019-09285-9

Eschenbach, D. A., Thwin, S. S., Patton, D. L., Hooton, T. M., Stapleton, A. E., Agnew, K., et al. (2000). Influence of the Normal Menstrual Cycle on Vaginal Tissue, Discharge, and Microflora. Clin. Infect. Dis. 30, 901-907. doi: 10.1086/ 313818

Etienne-Mesmin, L., Chassaing, B., Desvaux, M., De Paepe, K., Gresse, R., Sauvaitre, T., et al. (2019). Experimental Models to Study Intestinal Microbes-Mucus Interactions in Health and Disease. FEMS Microbiol. Rev. 43, 457-489. doi: 10.1093/femsre/fuz013

Farage, M., and Maibach, H. (2006). Lifetime Changes in the Vulva and Vagina. Arch. Gynecol. Obstet. 273, 195-202. doi: 10.1007/s00404-005-0079-x

Fernandez-Hermida, Y., Grande, G., Menarguez, M., Astorri, A. L., and Azagra, R. (2018). Proteomic Markers in Cervical Mucus. Protein Pept. Lett. 25, 463-471. doi: 10.2174/0929866525666180418122705

Gajer, P., Brotman, R. M., Bai, G., Sakamoto, J., Schutte, U. M., Zhong, X., et al. (2012). Temporal Dynamics of the Human Vaginal Microbiota. Sci. Transl. Med. 4, 132ra152. doi: 10.1126/scitranslmed.3003605

Gampa, A., Engen, P. A., Shobar, R., and Mutlu, E. A. (2017). Relationships Between Gastrointestinal Microbiota and Blood Group Antigens. Physiol. Genomics 49, 473-483. doi: 10.1152/physiolgenomics.00043.2017

Ghosh, M., Shen, Z., Fahey, J. V., Cu-Uvin, S., Mayer, K., and Wira, C. R. (2010). Trappin-2/Elafin: A Novel Innate Anti-Human Immunodeficiency Virus-1 Molecule of the Human Female Reproductive Tract. Immunology 129, 207219. doi: 10.1111/j.1365-2567.2009.03165.x

Gilbert, N. M., Lewis, W. G., Li, G., Sojka, D. K., Lubin, J. B., and Lewis, A. L. (2019). Gardnerella Vaginalis and Prevotella Bivia Trigger Distinct and Overlapping Phenotypes in a Mouse Model of Bacterial Vaginosis. J. Infect. Dis. 220, 1099-1108. doi: 10.1093/infdis/jiy704

Gipson, I. K. (2001). Mucins of the Human Endocervix. Front. Biosci. 6, D1245D1255. doi: 10.2741/gipson

Gipson, I. K., Ho, S. B., Spurr-Michaud, S. J., Tisdale, A. S., Zhan, Q., Torlakovic, E., et al. (1997). Mucin Genes Expressed by Human Female Reproductive Tract Epithelia. Biol. Reprod. 56, 999-1011. doi: 10.1095/biolreprod56.4.999

Gipson, I. K., Moccia, R., Spurr-Michaud, S., Argueso, P., Gargiulo, A. R., Hill, J. A., et al. (2001). The Amount of MUC5B Mucin in Cervical Mucus Peaks at Midcycle. J. Clin. Endocrinol. Metab. 86, 594-600. doi: 10.1210/jc.86.2.594

Gipson, I. K., Spurr-Michaud, S., Moccia, R., Zhan, Q., Toribara, N., Ho, S. B., et al. (1999). MUC4 and MUC5B Transcripts are the Prevalent Mucin Messenger
Ribonucleic Acids of the Human Endocervix. Biol. Reprod. 60, 58-64. doi: 10.1095/biolreprod60.1.58

Gliniewicz, K., Schneider, G. M., Ridenhour, B. J., Williams, C. J., Song, Y., Farage, M. A., et al. (2019). Comparison of the Vaginal Microbiomes of Premenopausal and Postmenopausal Women. Front. Microbiol. 10, 193. doi: 10.3389/fmicb.2019.00193

Gonzalez-Rodriguez, I., Sanchez, B., Ruiz, L., Turroni, F., Ventura, M., RuasMadiedo, P., et al. (2012). Role of Extracellular Transaldolase From Bifidobacterium Bifidum in Mucin Adhesion and Aggregation. Appl. Environ. Microbiol. 78, 3992-3998. doi: 10.1128/AEM.08024-11

Gosmann, C., Anahtar, M. N., Handley, S. A., Farcasanu, M., Abu-Ali, G., Bowman, B. A., et al. (2017). Lactobacillus-Deficient Cervicovaginal Bacterial Communities Are Associated With Increased HIV Acquisition in Young South African Women. Immunity 46, 29-37. doi: 10.1016/j.immuni. 2016.12.013

Gupta, P., Singh, M. P., and Goyal, K. (2020). Diversity of Vaginal Microbiome in Pregnancy: Deciphering the Obscurity. Front. Public Health 8, 326. doi: 10.3389/fpubh.2020.00326

Hein, M., Valore, E. V., Helmig, R. B., Uldbjerg, N., and Ganz, T. (2002). Antimicrobial Factors in the Cervical Mucus Plug. Am. J. Obstet. Gynecol. 187, 137-144. doi: 10.1067/mob.2002.123034

Henderson, M. H., Couchman, G. M., Walmer, D. K., Peters, J. J., Owen, D. H., Brown, M. A., et al. (2007). Optical Imaging and Analysis of Human Vaginal Coating by Drug Delivery Gels. Contraception 75, 142-151. doi: 10.1016/ j.contraception.2006.08.014

Herbst-Kralovetz, M. M., Pyles, R. B., Ratner, A. J., Sycuro, L. K., and Mitchell, C. (2016). New Systems for Studying Intercellular Interactions in Bacterial Vaginosis. J. Infect. Dis. 214 Suppl;1, S6-S13. doi: 10.1093/infdis/jiw130

Hickey, R. J., Zhou, X., Settles, M. L., Erb, J., Malone, K., Hansmann, M. A., et al. (2015). Vaginal Microbiota of Adolescent Girls Prior to the Onset of Menarche Resemble Those of Reproductive-Age Women. mBio 6 (2), e00097-15. doi: 10.1128/mBio.00097-15

Hillier, S. L., and Lau, R. J. (1997). Vaginal Microflora in Postmenopausal Women Who Have Not Received Estrogen Replacement Therapy. Clin. Infect. Dis. 25 Suppl;2, S123-S126. doi: 10.1086/516221

Hillier, S. L., Martius, J., Krohn, M., Kiviat, N., Holmes, K. K., and Eschenbach, D. A. (1988). A Case-Control Study of Chorioamnionic Infection and Histologic Chorioamnionitis in Prematurity. N Engl. J. Med. 319, 972-978. doi: 10.1056/ NEJM198810133191503

Hillier, S. L., Nugent, R. P., Eschenbach, D. A., Krohn, M. A., Gibbs, R. S., Martin, D. H., et al. (1995). Association Between Bacterial Vaginosis and Preterm Delivery of a Low-Birth-Weight Infant. The Vaginal Infections and Prematurity Study Group. N Engl. J. Med. 333, 1737-1742. doi: 10.1056/ NEJM199512283332604

Hoang, T., Toler, E., Delong, K., Mafunda, N. A., Bloom, S. M., Zierden, H. C., et al. (2020). The Cervicovaginal Mucus Barrier to HIV-1 Is Diminished in Bacterial Vaginosis. PloS Pathog. 16, e1008236. doi: 10.1371/ journal.ppat.1008236

Howe, L., Wiggins, R., Soothill, P. W., Millar, M. R., Horner, P. J., and Corfield, A. P. (1999). Mucinase and Sialidase Activity of the Vaginal Microflora: Implications for the Pathogenesis of Preterm Labour. Int. J. STD AIDS 10, 442-447. doi: 10.1258/0956462991914438

Huggins, G. R., and Preti, G. (1981). Vaginal Odors and Secretions. Clin. Obstet. Gynecol. 24, 355-377. doi: 10.1097/00003081-198106000-00005

Ingber, D. E. (2021). Enabling Out-of-Body Experiences for Living Organs. J. Exp. Med. 218 (4), e20201756. doi: 10.1084/jem.20201756

Johansson, M. E., and Hansson, G. C. (2016). Immunological Aspects of Intestinal Mucus and Mucins. Nat. Rev. Immunol. 16, 639-649. doi: 10.1038/nri.2016.88

Johansson, M. E., Jakobsson, H. E., Holmen-Larsson, J., Schutte, A., Ermund, A., Rodriguez-Pineiro, A. M., et al. (2015). Normalization of Host Intestinal Mucus Layers Requires Long-Term Microbial Colonization. Cell Host Microbe 18, 582-592. doi: 10.1016/j.chom.2015.10.007

Johansson, M. E., Phillipson, M., Petersson, J., Velcich, A., Holm, L., and Hansson, G. C. (2008). The Inner of the Two Muc2 Mucin-Dependent Mucus Layers in Colon is Devoid of Bacteria. Proc. Natl. Acad. Sci. U.S.A. 105, 15064-15069. doi: $10.1073 /$ pnas.0803124105

Johnson, S. R., Petzold, C. R., and Galask, R. P. (1985). Qualitative and Quantitative Changes of the Vaginal Microbial Flora During the Menstrual 
Cycle. Am. J. Reprod. Immunol. Microbiol. 9, 1-5. doi: 10.1111/j.16000897.1985.tb00331.x

Kairys, N., and Garg, M. (2020). “Gardnerella,” In: StatPearls. (Treasure Island (FL): StatPearls Publishing.

Kavanaugh, N. L., Zhang, A. Q., Nobile, C. J., Johnson, A. D., and Ribbeck, K. (2014). Mucins Suppress Virulence Traits of Candida Albicans. mBio 5, e01911. doi: 10.1128/mBio.01911-14

Keller, M. J., Guzman, E., Hazrati, E., Kasowitz, A., Cheshenko, N., Wallenstein, S., et al. (2007). PRO 2000 Elicits a Decline in Genital Tract Immune Mediators Without Compromising Intrinsic Antimicrobial Activity. AIDS 21, 467-476. doi: 10.1097/QAD.0b013e328013d9b5

Klotman, M. E., and Chang, T. L. (2006). Defensins in Innate Antiviral Immunity. Nat. Rev. Immunol. 6, 447-456. doi: 10.1038/nri1860

Kobayashi, M., Lee, H., Nakayama, J., and Fukuda, M. (2009). Roles of Gastric Mucin-Type O-Glycans in the Pathogenesis of Helicobacter Pylori Infection. Glycobiology 19, 453-461. doi: 10.1093/glycob/cwp004

Kolde, R., Franzosa, E. A., Rahnavard, G., Hall, A. B., Vlamakis, H., Stevens, C., et al. (2018). Host Genetic Variation and its Microbiome Interactions Within the Human Microbiome Project. Genome Med. 10, 6. doi: 10.1186/s13073-0180515-8

Lacroix, G., Gouyer, V., Gottrand, F., and Desseyn, J. L. (2020). The Cervicovaginal Mucus Barrier. Int. J. Mol. Sci. 21 (21), 8266. doi: 10.3390/ ijms21218266

Lai, S. K., Hida, K., Shukair, S., Wang, Y. Y., Figueiredo, A., Cone, R., et al. (2009). Human Immunodeficiency Virus Type 1 Is Trapped by Acidic But Not by Neutralized Human Cervicovaginal Mucus. J. Virol. 83, 11196-11200. doi: 10.1128/JVI.01899-08

Lehker, M. W., and Sweeney, D. (1999). Trichomonad Invasion of the Mucous Layer Requires Adhesins, Mucinases, and Motility. Sex Transm. Infect. 75, 231238. doi: 10.1136/sti.75.4.231

Levinson, P., Kaul, R., Kimani, J., Ngugi, E., Moses, S., Macdonald, K. S., et al. (2009). Levels of Innate Immune Factors in Genital Fluids: Association of Alpha Defensins and LL-37 With Genital Infections and Increased HIV Acquisition. AIDS 23, 309-317. doi: 10.1097/QAD.0b013e328321809c

Lewis, W. G., Robinson, L. S., Gilbert, N. M., Perry, J. C., and Lewis, A. L. (2013). Degradation, Foraging, and Depletion of Mucus Sialoglycans by the VaginaAdapted Actinobacterium Gardnerella Vaginalis. J. Biol. Chem. 288, 1206712079. doi: 10.1074/jbc.M113.453654

Li, H., Limenitakis, J. P., Fuhrer, T., Geuking, M. B., Lawson, M. A., Wyss, M., et al. (2015). The Outer Mucus Layer Hosts a Distinct Intestinal Microbial Niche. Nat. Commun. 6, 8292. doi: 10.1038/ncomms9292

Li, X., Wang, L., Nunes, D. P., Troxler, R. F., and Offner, G. D. (2003). ProInflammatory Cytokines Up-Regulate MUC1 Gene Expression in Oral Epithelial Cells. J. Dent. Res. 82, 883-887. doi: 10.1177/154405910308201107

Mall, A. S., Habte, H., Mthembu, Y., Peacocke, J., and De Beer, C. (2017). Mucus and Mucins: Do They Have a Role in the Inhibition of the Human Immunodeficiency Virus? Virol. J. 14, 192. doi: 10.1186/s12985-017-0855-9

McGregor, J. A., French, J. I., Jones, W., Milligan, K., Mckinney, P. J., Patterson, E., et al. (1994). Bacterial Vaginosis is Associated With Prematurity and Vaginal Fluid Mucinase and Sialidase: Results of a Controlled Trial of Topical Clindamycin Cream. Am. J. Obstet. Gynecol. 170, 1048-1059; discussion 1059-1060. doi: 10.1016/S0002-9378(94)70098-2

McLoughlin, K., Schluter, J., Rakoff-Nahoum, S., Smith, A. L., and Foster, K. R. (2016). Host Selection of Microbiota via Differential Adhesion. Cell Host Microbe 19, 550-559. doi: 10.1016/j.chom.2016.02.021

Menarguez, M., Pastor, L. M., and Odeblad, E. (2003). Morphological Characterization of Different Human Cervical Mucus Types Using Light and Scanning Electron Microscopy. Hum. Reprod. 18, 1782-1789. doi: 10.1093/ humrep/deg382

Mirmonsef, P., Hotton, A. L., Gilbert, D., Burgad, D., Landay, A., Weber, K. M., et al. (2014). Free Glycogen in Vaginal Fluids is Associated With Lactobacillus Colonization and Low Vaginal pH. PloS One 9, e102467. doi: 10.1371/ journal.pone.0102467

Mirmonsef, P., Modur, S., Burgad, D., Gilbert, D., Golub, E. T., French, A. L., et al. (2015). Exploratory Comparison of Vaginal Glycogen and Lactobacillus Levels in Premenopausal and Postmenopausal Women. Menopause 22, 702-709. doi: 10.1097/GME.0000000000000397
Mitchell, C., Fredricks, D., Agnew, K., and Hitti, J. (2015). Hydrogen PeroxideProducing Lactobacilli Are Associated With Lower Levels of Vaginal Interleukin-1beta, Independent of Bacterial Vaginosis. Sex. Transm. Dis. 42, 358-363. doi: 10.1097/OLQ.0000000000000298

Mitsukawa, K., Otsuki, K., Yanaihara, A., Sawada, M., Iwasaki, S., and Okai, T. (2006). Concentration of Lactoferrin and Interleukin-6 in Cervical Mucus From Patients Being Treated for Infertility. Reprod. Med. Biol. 5, 105-109. doi: 10.1007/BF03016146

Moncla, B. J., Chappell, C. A., Debo, B. M., and Meyn, L. A. (2016). The Effects of Hormones and Vaginal Microflora on the Glycome of the Female Genital Tract: Cervical-Vaginal Fluid. PloS One 11, e0158687. doi: 10.1371/ journal.pone.0158687

Moriyama, A., Shimoya, K., Ogata, I., Kimura, T., Nakamura, T., Wada, H., et al. (1999). Secretory Leukocyte Protease Inhibitor (SLPI) Concentrations in Cervical Mucus of Women With Normal Menstrual Cycle. Mol. Hum. Reprod. 5, 656-661. doi: 10.1093/molehr/5.7.656

Muscariello, L., De Siena, B., and Marasco, R. (2020). Lactobacillus Cell Surface Proteins Involved in Interaction With Mucus and Extracellular Matrix Components. Curr. Microbiol. 77, 3831-3841. doi: 10.1007/s00284-02002243-5

Najmabadi, S., Schliep, K. C., Simonsen, S. E., Porucznik, C. A., Egger, M. J., and Stanford, J. B. (2021). Cervical Mucus Patterns and the Fertile Window in Women Without Known Subfertility: A Pooled Analysis of Three Cohorts. Hum. Reprod. 36 (7), 1784-1795. doi: 10.1093/humrep/deab049

Nasioudis, D., Beghini, J., Bongiovanni, A. M., Giraldo, P. C., Linhares, I. M., and Witkin, S. S. (2015). Alpha-Amylase in Vaginal Fluid: Association With Conditions Favorable to Dominance of Lactobacillus. Reprod. Sci. 22, 1393 1398. doi: $10.1177 / 1933719115581000$

Nunn, K. L., Wang, Y. Y., Harit, D., Humphrys, M. S., Ma, B., Cone, R., et al. (2015). Enhanced Trapping of HIV-1 by Human Cervicovaginal Mucus Is Associated With Lactobacillus Crispatus-Dominant Microbiota. mBio 6, e01084-e01015. doi: 10.1128/mBio.01084-15

Odeblad, E. (1983). The Biophysical Properties of Cervical-Vaginal Secretions. Int. Rev. Nat. Fam. Plann. 7, 1-56.

Odeblad, E. (1997). Cervical Mucus and Their Functions. J. Ir. Coll. Physicians Surg. 26, 27-32.

Olmsted, S. S., Meyn, L. A., Rohan, L. C., and Hillier, S. L. (2003). Glycosidase and Proteinase Activity of Anaerobic Gram-Negative Bacteria Isolated From Women With Bacterial Vaginosis. Sex. Transm. Dis. 30, 257-261. doi: 10.1097/00007435-200303000-00016

Padmavathi, T., Bhargavi, R., Priyanka, P. R., Niranjan, N. R., and Pavitra, P. V. (2018). Screening of Potential Probiotic Lactic Acid Bacteria and Production of Amylase and its Partial Purification. J. Genet. Eng. Biotechnol. 16, 357-362. doi: 10.1016/j.jgeb.2018.03.005

Paone, P., and Cani, P. D. (2020). Mucus Barrier, Mucins and Gut Microbiota: The Expected Slimy Partners? Gut 69, 2232-2243. doi: 10.1136/gutjnl-2020-322260

Pleckaityte, M., Janulaitiene, M., Lasickiene, R., and Zvirbliene, A. (2012). Genetic and Biochemical Diversity of Gardnerella Vaginalis Strains Isolated From Women With Bacterial Vaginosis. FEMS Immunol. Med. Microbiol. 65, 69-77. doi: 10.1111/j.1574-695X.2012.00940.x

Radtke, A. L., Quayle, A. J., and Herbst-Kralovetz, M. M. (2012). Microbial Products Alter the Expression of Membrane-Associated Mucin and Antimicrobial Peptides in a Three-Dimensional Human Endocervical Epithelial Cell Model. Biol. Reprod. 87, 132. doi: 10.1095/biolreprod. 112.103366

Rausch, P., Rehman, A., Kunzel, S., Hasler, R., Ott, S. J., Schreiber, S., et al. (2011). Colonic Mucosa-Associated Microbiota is Influenced by an Interaction of Crohn Disease and FUT2 (Secretor) Genotype. Proc. Natl. Acad. Sci. U.S.A. 108, 19030-19035. doi: 10.1073/pnas.1106408108

Ravel, J., Gajer, P., Abdo, Z., Schneider, G. M., Koenig, S. S., Mcculle, S. L., et al. (2011). Vaginal Microbiome of Reproductive-Age Women. Proc. Natl. Acad. Sci. U.S.A. 108 Suppl;1, 4680-4687. doi: 10.1073/pnas.1002611107

Reynoso-Prieto, M., Takeda, M., Prakobphol, A., Seidman, D., Averbach, S., Fisher, S., et al. (2019). Menstrual Cycle-Dependent Alterations in Glycosylation: A Roadmap for Defining Biomarkers of Favorable and Unfavorable Mucus. J. Assist. Reprod. Genet. 36, 847-855. doi: 10.1007/ s10815-019-01412-1 
Robbe, C., Capon, C., Coddeville, B., and Michalski, J. C. (2004). Structural Diversity and Specific Distribution of O-Glycans in Normal Human Mucins Along the Intestinal Tract. Biochem. J. 384, 307-316. doi: 10.1042/BJ20040605

Santiago, G. L., Deschaght, P., El Aila, N., Kiama, T. N., Verstraelen, H., Jefferson, K. K., et al. (2011). Gardnerella Vaginalis Comprises Three Distinct Genotypes of Which Only Two Produce Sialidase. Am. J. Obstet. Gynecol. 204, 450 e451-457.

Santiago, G. L., Tency, I., Verstraelen, H., Verhelst, R., Trog, M., Temmerman, M., et al. (2012). Longitudinal qPCR Study of the Dynamics of L. Crispatus, L. Iners, A. Vaginae, (Sialidase Positive) G. Vaginalis and P. Bivia in the Vagina. PloS One 7, e45281.

Schauer, R. (2009). Sialic Acids as Regulators of Molecular and Cellular Interactions. Curr. Opin. Struct. Biol. 19, 507-514. doi: 10.1016/j.sbi. 2009.06.003

Schroeder, B. O. (2019). Fight Them or Feed Them: How the Intestinal Mucus Layer Manages the Gut Microbiota. Gastroenterol. Rep. (Oxf.) 7, 3-12. doi: 10.1093/gastro/goy052

Schroeder, H. A., Nunn, K. L., Schaefer, A., Henry, C. E., Lam, F., Pauly, M. H., et al. (2018). Herpes Simplex Virus-Binding IgG Traps HSV in Human Cervicovaginal Mucus Across the Menstrual Cycle and Diverse Vaginal Microbial Composition. Mucosal Immunol. 11, 1477-1486. doi: 10.1038/ s41385-018-0054-Z

Schumacher, G. F., Kim, M. H., Hosseinian, A. H., and Dupon, C. (1977). Immunoglobulins, Proteinase Inhibitors, Albumin, and Lysozyme in Human Cervical Mucus. I. Communication: Hormonal Profiles and Cervical Mucus Changes-Methods and Results. Am. J. Obstet. Gynecol. 129, 629-636. doi: 10.1016/0002-9378(77)90644-5

Shimoya, K., Zhang, Q., Temma, K., Kimura, T., Tsujie, T., Tsutsui, T., et al. (2006). Secretory Leukocyte Protease Inhibitor Levels in Cervicovaginal Secretion of Elderly Women. Maturitas 54, 141-148. doi: 10.1016/ j.maturitas.2004.02.019

Shust, G. F., Cho, S., Kim, M., Madan, R. P., Guzman, E. M., Pollack, M., et al. (2010). Female Genital Tract Secretions Inhibit Herpes Simplex Virus Infection: Correlation With Soluble Mucosal Immune Mediators and Impact of Hormonal Contraception. Am. J. Reprod. Immunol. 63, 110-119. doi: 10.1111/j.1600-0897.2009.00768.x

Smayevsky, J., Canigia, L. F., Lanza, A., and Bianchini, H. (2001). Vaginal Microflora Associated With Bacterial Vaginosis in Nonpregnant Women: Reliability of Sialidase Detection. Infect. Dis. Obstet. Gynecol. 9, 17-22. doi: 10.1155/S1064744901000047

Smirnova, M. G., Guo, L., Birchall, J. P., and Pearson, J. P. (2003). LPS UpRegulates Mucin and Cytokine mRNA Expression and Stimulates Mucin and Cytokine Secretion in Goblet Cells. Cell Immunol. 221, 42-49. doi: 10.1016/ S0008-8749(03)00059-5

Smith-Dupont, K. B., Wagner, C. E., Witten, J., Conroy, K., Rudoltz, H., Pagidas, K., et al. (2017). Probing the Potential of Mucus Permeability to Signify Preterm Birth Risk. Sci. Rep. 7, 10302. doi: 10.1038/s41598-017-08057-z

Spear, G. T., French, A. L., Gilbert, D., Zariffard, M. R., Mirmonsef, P., Sullivan, T. H., et al. (2014). Human Alpha-Amylase Present in Lower-Genital-Tract Mucosal Fluid Processes Glycogen to Support Vaginal Colonization by Lactobacillus. J. Infect. Dis. 210, 1019-1028. doi: 10.1093/infdis/jiu231

Srinivasan, S., and Fredricks, D. N. (2008). The Human Vaginal Bacterial Biota and Bacterial Vaginosis. Interdiscip. Perspect. Infect. Dis. 2008, 750479. doi: $10.1155 / 2008 / 750479$

Svare, J. A., Schmidt, H., Hansen, B. B., and Lose, G. (2006). Bacterial Vaginosis in a Cohort of Danish Pregnant Women: Prevalence and Relationship With Preterm Delivery, Low Birthweight and Perinatal Infections. BJOG 113, 14191425. doi: 10.1111/j.1471-0528.2006.01087.x

Tailford, L. E., Crost, E. H., Kavanaugh, D., and Juge, N. (2015). Mucin Glycan Foraging in the Human Gut Microbiome. Front. Genet. 6, 81. doi: 10.3389/ fgene.2015.00081

Thomsson, K. A., Schulz, B. L., Packer, N. H., and Karlsson, N. G. (2005). MUC5B Glycosylation in Human Saliva Reflects Blood Group and Secretor Status. Glycobiology 15, 791-804. doi: 10.1093/glycob/cwi059

Vaishnava, S., Yamamoto, M., Severson, K. M., Ruhn, K. A., Yu, X., Koren, O., et al. (2011). The Antibacterial Lectin RegIIIgamma Promotes the Spatial
Segregation of Microbiota and Host in the Intestine. Science 334, 255-258. doi: $10.1126 /$ science. 1209791

Valore, E. V., Park, C. H., Igreti, S. L., and Ganz, T. (2002). Antimicrobial Components of Vaginal Fluid. Am. J. Obstet. Gynecol. 187, 561-568. doi: 10.1067/mob.2002.125280

van Der Veer, C., Hertzberger, R. Y., Bruisten, S. M., Tytgat, H. L. P., Swanenburg, J., De Kat Angelino-Bart, A., et al. (2019). Comparative Genomics of Human Lactobacillus Crispatus Isolates Reveals Genes for Glycosylation and Glycogen Degradation: Implications for In Vivo Dominance of the Vaginal Microbiota. Microbiome 7, 49. doi: 10.1186/s40168-019-0667-9

Van Tassell, M. L., and Miller, M. J. (2011). Lactobacillus Adhesion to Mucus. Nutrients 3, 613-636. doi: 10.3390/nu3050613

Varki, R. A., Cummings, R. D., Esko, J. D., Stanley, P., Hart, G. W., Aebi, M., Darvill, A. G., Kinoshita, T., Packer, N. H., Prestegard, J. H., Schnaar, R. L., and Seeberger, P. H. (Eds.) (2015). Essentials of Glycobiology. Cold Spring Harbor (NY): Cold Spring Harbor Laboratory Press.

Velez, M. P., De Keersmaecker, S. C., and Vanderleyden, J. (2007). Adherence Factors of Lactobacillus in the Human Gastrointestinal Tract. FEMS Microbiol. Lett. 276, 140-148. doi: 10.1111/j.1574-6968.2007.00908.x

Werlang, C., Cárcarmo-Oyarce, G., and Ribbeck, K. (2019). Engineering Mucus to Study and Influence the Microbiome. Nat. Rev. Mater. 4, 134-145. doi: 10.1038/s41578-018-0079-7

Wheeler, K. M., Carcamo-Oyarce, G., Turner, B. S., Dellos-Nolan, S., Co, J. Y., Lehoux, S., et al. (2019). Mucin Glycans Attenuate the Virulence of Pseudomonas Aeruginosa in Infection. Nat. Microbiol. 4, 2146-2154. doi: 10.1038/s41564-019-0581-8

Wira, C. R., Patel, M. V., Ghosh, M., Mukura, L., and Fahey, J. V. (2011). Innate Immunity in the Human Female Reproductive Tract: Endocrine Regulation of Endogenous Antimicrobial Protection Against HIV and Other Sexually Transmitted Infections. Am. J. Reprod. Immunol. 65, 196-211. doi: 10.1111/ j.1600-0897.2011.00970.x

Witkin, S. S., Mendes-Soares, H., Linhares, I. M., Jayaram, A., Ledger, W. J., and Forney, L. J. (2013). Influence of Vaginal Bacteria and D- and L-Lactic Acid Isomers on Vaginal Extracellular Matrix Metalloproteinase Inducer: Implications for Protection Against Upper Genital Tract Infections. mBio 4. doi: $10.1128 / \mathrm{mBio} .00460-13$

Xu, J., Holzman, C. B., Arvidson, C. G., Chung, H., and Goepfert, A. R. (2008). Midpregnancy Vaginal Fluid Defensins, Bacterial Vaginosis, and Risk of Preterm Delivery. Obstet. Gynecol. 112, 524-531. doi: 10.1097/AOG. 0b013e318184209b

Yarbrough, V. L., Winkle, S., and Herbst-Kralovetz, M. M. (2015). Antimicrobial Peptides in the Female Reproductive Tract: A Critical Component of the Mucosal Immune Barrier With Physiological and Clinical Implications. Hum. Reprod. Update 21, 353-377. doi: 10.1093/humupd/dmu065

Zegels, G., Van Raemdonck, G. A., Tjalma, W. A., and Van Ostade, X. W. (2010). Use of Cervicovaginal Fluid for the Identification of Biomarkers for Pathologies of the Female Genital Tract. Proteome Sci. 8, 63. doi: 10.1186/ 1477-5956-8-63

Zhou, X., Brown, C. J., Abdo, Z., Davis, C. C., Hansmann, M. A., Joyce, P., et al. (2007). Differences in the Composition of Vaginal Microbial Communities Found in Healthy Caucasian and Black Women. ISME J. 1, 121-133. doi: 10.1038/ismej.2007.12

Conflict of Interest : CM receives grant funding from Merck, and has served as a consultant for Scynexis Inc.

The remaining author declares that the research was conducted in the absence of any commercial or financial relationships that could be construed as a potential conflict of interest.

Copyright (c) 2021 Vagios and Mitchell. This is an open-access article distributed under the terms of the Creative Commons Attribution License (CC BY). The use, distribution or reproduction in other forums is permitted, provided the original author(s) and the copyright owner(s) are credited and that the original publication in this journal is cited, in accordance with accepted academic practice. No use, distribution or reproduction is permitted which does not comply with these terms. 